\title{
Studi Kasus Ibu Melakukan Kunjungan Ulang Pada Balita Pneumonia Di Wilayah Kerja Puskesmas Landasan Ulin Kalimantan Selatan
}

\author{
Case Study Mom Doing Re-Visit In The Pneumonia In The Working Area Health Center \\ Landasan Ulin South Kalimantan \\ Eka Handayani ${ }^{* *}$ Septi Anggraeni ${ }^{1}$ \\ ${ }^{1}$ Fakultas Kesehatan Masyarakat Universitas Islam Kalimantan MAB Banjarmasin \\ JI. Adhyaksa No. 2 Kota Banjarmasin \\ *Korespondensi: Ekabella8888@gmail.com
}

\begin{abstract}
Acute respiratory infections affect many children, both in developing countries and in developed countries. acute respiratory infections that affect death and often affect children under 5 years of age, namely pneumonia. Pneumonia is the main killer of toddlers in the world with a higher prevalence compared to AIDS, malaria and measles. Every year, it is estimated that more than 2 million children under five die from Pneumonia (1 toddler / 20 seconds) from 9 million total deaths of children under five in the world. In Indonesia, pneumonia is still a big problem considering the mortality rate from this disease is still high.. Knowing the mother's case studies do repeat visits in infants pneumonia in health center Landasan Ulin. A qualitative study through interviews and documentation to one health worker. Not all mothers bring their babies repeated visit only $30 \%$ of mothers who commit repeated visit of all children under five suffering from pneumonia. Mother toddler who do repeat visits by $35 \%$ means that more mothers who do not do repeat visits by $65 \%$ this is because there are several reasons mothers do not bring toddlers pneumonia to re-visit them her son had recovered and did not cough again, there also reasoned mothers are busy.
\end{abstract}

Keywords: Repeat visit in pneumonia infants

\section{Pendahuluan}

Penyakit yang banyak diderita oleh masyarakat adalah ISPA (Infeksi Saluran Pernapasan Akut) yaitu penyakit yang meliputi infeksi akut saluran pernapasan bagian atas dan infeksi akut saluran pernapasan bagian bawah. ISPA banyak menyerang anak-anak, baik di negara berkembang maupun di negara maju. ISPA yang berdampak pada kematian dan sering menyerang pada anak bawah 5 tahun yaitu pneumonia. Penyakit pneumonia atau biasa yang disebut the one killer of childern merupakan salah satu masalah utama kesehatan masyarakat (1).

Di negara berkembang, pneumonia merupakan penyakit yang terabaikan the neglected disease atau penyakit yang terlupakan the forgotten disease karena begitu banyak anak yang meninggal akibat pneumonia, namun masalah penyakit pneumonia tidak mendapat perhatian (2).

Pneumonia adalah pembunuh utama balita di dunia yang prevalensinya lebih banyak dibandingkan dengan penyakit AIDS, malaria, dan campak. Setiap tahun diperkirakan lebih dari 2 juta balita meninggal karena Pneumonia (1 balita/20 detik) dari 9 juta total kematian balita di dunia. Diantara 5 kematian balita, 1 diantaranya disebabkan oleh pneumonia (3). $\mathrm{Di}$ Indonesia, pneumonia masih merupakan masalah besar mengingat angka kematian akibat penyakit ini masih tinggi. Berdasarkan SDKI (Survei Demografi Kesehatan Indonesia) pada tahun 2012, angka kematian bayi 32/1.000 kelahiran hidup, angka kematian balita 40/1000 kelahiran hidup, lebih dari $3 / 4$ kematian balita tahun pertama kehidupan, terbanyak saat neonatus. Hasil survey Sistem Registrasi Sampel (SRS) oleh Badan penelitian dan Pengembangan Kesehatan Kementrian Kesehatan tahun 2014 menyebutkan proporsi kematian pneumonia pada balita di Indonesia sebesar 9,4\% (4).

Menurut catatan Dinas Kesehatan Kalimantan Selatan, sepanjang tahun 2014 tercatat 14 balita meninggal akibat serangan pneumonia. Jumlah penderita pneumonia di 13 kabupaten kota di Provinsi Kalimantan Selatan ini tercatat mencapai 111.590 
orang, terdiri dari 52.130 balita dan 54.460 di atas usia lima tahun. Data Dinas Kesehatan Kota Banjarbaru sepanjang tahun 2015 penderita pneumonia mencapai 797 balita dan 366 orang anak yang usia diatas 5 tahun. (5)

Penatalaksanaan penyakit pneumonia berdasarkan Manajemen Terpadu Balita Sakit (MTBS) yakni dengan pemberian antibiotik seperti kotrimoksazol, amoksisilin, dan ampisilin. Antibiotik untuk pneumonia diberikan selama 3 hari, dan setelah 3 hari pasien harus melakukan kunjungan ulang (6).

Hal tersebut menjadi sangat penting karena untuk menilai keadaan klinis pasien apakah sembuh atau tidak. Jika sembuh dilanjutkan pengobatan selama 3 hari tapi jika tidak sembuh maka dilakukan kunjungan ulang. Kunjungan ulang sama dengan pemeriksaan pertama namun pengobatan yang diberikan pada kunjungan ulang biasanya berbeda dengan pengobatan pada waktu kunjungan pertama. Tindakan dan pengobatan kunjungan ulang dilakukan berdasarkan tanda-tanda yang ada pada anak saat kunjungan ulang seperti frekuensi napas atau nafsu makan anak apabila tidak menunjukkan perbaikan gantilah dengan antibiotik pilihan kedua dan anjurkan ibu untuk kembali 2 hari. Jika ada tanda bahaya umum seperti tarikan dinding dada kedalam maka beri dosis antibiotik pra rujukan dan lakukan rujuk segera. (7).

Berdasarkan latar belakang di atas peneliti tertarik untuk melakukan penelitian dengan judul "Studi Kasus Ibu Melakukan Kunjungan Ulang Pada Balita Pneumonia Di wilayah Kerja Puskesmas Landasan Ulin"

\section{Metode Penelitian}

Penelitian ini merupakan penelitian deskriptif kualitatif. Penelitian ini menggunakan pendekatan cross sectional. Subjek penelitian ini adalah tenaga kesehatan yang menangani balita dengan pneumonia. Jumlah subjek dalam penelitian ini adalah 1 orang.

\section{Hasil Penelitian}

Penelitian ini berlangsung pada tanggal 7 November 2018 di Puskesmas Landasan Ulin. Banyaknya informan terdiri dari 1 perawat. Data-data mengenai identitas informan dapat dilihat pada lampiran II. Hasil pengumpulan data melalui wawancara mendalam adalah sebagai berikut:

Berdasarkan informan atas nama $A$ (30 tahun) dengan latar belakang pendidikan terakhir DIII perawat mengatakan:

a) Apakah kunjungan ulang penderita pneumonia itu penting?

Kunjungan ulang pneumonia itu penting... tujuannya adalah kita mengevaluasi pengobatan... pertama apakah obat-obatan itu,obat-obat yang diminum itu bekerja dengan baik efektif..., kemudian hitung nafas kembali dan junga mengukur kepedulian ibu terhadap anaknya tentang sakit anaknya yang pneumonia itu.

b) Apakah ibu yang membawa anak balita dengan pneumonia selalu melakukan kunjungan ulang?

Tidak selalu, karena memang semua petugas di poli MTBS itu menyuruh untuk kunjungan ulang dua hari tapi tidak semua datang... hanya sebagian aja yang mematuhi petugas kesehatan untuk kunjungan ulang, yaa sekitar 35\% dari penderita pneumonia yang mau melakukan kunjungan ulang .

c) Apakah petugas kesehatan selalu mengingatkan untuk kunjungan ulang setelah dua hari kunjungan yang pertama?

lya, iya... kami selalu mengingatkan kepada parien dan keluarga pasien yang mendampingi karena di MTBS memang petugas diwajibkan untuk memberikan saran kepada pasien dan keluarga untuk kontrol ulang dua hari setelah pemeriksaan.

d) Apakah petugas kesehatan selalu memotivasi ibu balita untuk mewajibkan membawa anaknya kunjungan ulang dua hari berikutnya?

lya tentu... pasti kita motivasi untuk datang.... Dan kita jelaskan Tujuankunjungan ulang yaitu untuk mengevaluasi pengobatan balitanya.

e) Apa alasan ibu yang tidak bisa membawa balita untuk kunjungan ulang?

Banyak alasan ibu-ibu tidak membawa anaknya kunjungan ulang diantaranya ibu mengatakan anaknya sudah tidak batuk lagi, ada yang mengatakan beliau bekerja 
dan tidak bisa mengantar anaknya untuk kontrol ulang.

\section{Pembahasan}

Menurut hasil penelitian tidak semua ibu balita membawa kunjungan ulang balitanya, dari hasil penelitian didapatkan hanya $35 \%$ ibu balita yang melakukan kunjungan ulang artinya lebih banyak ibu balita yang tidak melakukan kunjungan ulang sebesar $65 \%$ hal ini karena ada beberapa alasan ibu balita tidak membawa balita penderita pneumonia untuk kunjungan ulang diantaranya anaknya sudah sembuh dan tidak batuk lagi, ada juga ibu balita beralasan sedang bekerja sehingga tidak bisa mengantar anaknya kunjungan ulang. Hal ini dapat disimpulkan bahwa masih rendahnya pengetahuan orang tua penderita pneumonia tentang kunjungan ulang pneumonia.

Hal ini sejalan dengan penelitian Vitasari (2011) dengan judul Hubungan Kepatuhan Kunjungan Ulang Dengan Membaiknya Pneumonia Pada Balita Di Puskesmas Piyungan Bantul Yogyakarta. Didapatkan hasil paling banyak ibu balita tidak melakukan kunjungan ulang sebesar $67 \%$ dan dengan alasan tidak melakukan kunjungan ulang sesuai dengan anjuran dari tenaga kesehatan adalah bahwa anaknya membaik dengan menurunnya gejala seperti batuk mulai membaik, panas menurun, pernafasan mulai membaik dan nafsu makan mulai membaik. (8)

Balita yang patuh melakukan kunjungan ulang dan yang tidak patuh melakukan kunjungan ulang belum tentu mengalami kesembuhan. Kesembuhan pneumonia tidak hanya dipengaruhi oleh kepatuhan kunjungan ulang, tetapi ada faktor lain yaitu pengobatan dan perawatan yang termasuk variabel antara. Hasil penelitian yang didapatkan dari data rekam medis menunjukkan bahwa balita yang sembuh pneumonia ditandai dengan frekuensi pernafasan melambat, dan demam menurun tetapi masih dilanjutkan pemberian antibiotik sampai 3 hari. Kesembuhan pneumonia dipengaruhi oleh pengobatan yang diberikan pada saat melakukan kunjungan ulang. Perawatan untuk kesembuhan pneumonia juga mempengaruhi perbaikan kondisi pneumonia karena apabila perawatan yang sesuai dengan yang dinasehatkan oleh tenaga kesehatan dijalankan dengan baik maka akan membantu kesembuhan pneumonia pada balita (9).

Sesuai dengan kebijakan Program Pemberantasan Penyakit Infeksi Saluran Pernafasan Akut (P2ISPA), antibiotika yang dipakai untuk pengobatan pneumonia adalah kotrimoksazol dengan pemberian selama 3 hari. Antibiotika yang dapat dipakai sebagai pengganti kotrimoksazol ialah ampisilin, amoksisilin, dan prokain penisilin (6).

Kepatuhan didefinisikan sebagai sejauh mana perilaku pasien sesuai dengan ketentuan yang diberikan oleh profesional kesehatan. Tingkat kepatuhan ibu balita dalam kunjungan ulang pada program MTBS sangat mempengaruhi tingkat kesembuhan balitanya sehingga hal ini perlu dijelaskan lebih dalam lagi tentang pentingnya melakukan kunjungan ulang. Tingkat kepatuhan ibu balita dalam kunjungan ulang pada program MTBS kemungkinan dipengaruhi oleh pengertian tentang tingkat kesembuhan, bila gejala yang diderita sudah hilang maka penyakit dianggap sudah sembuh. Jika hal ini terjadi penyakit yang diderita balita tersebut akan lebih mudah kambuh lagi karena belum sembuh secara optimal. (8)

Menurut penelitian Pradana (2016) ada beberapa faktor yang mempengaruhi kepatuhan salah satunya pengetahuan responden dimana hasil penelitiannya ada hubungan antara pengetahuan ibu dengan kepatuhan kunjungan ulang dikarenakan pengetahuan ibu yang kurang akan berdampak pada ketidak patuhan untuk melakukan kunjungan ulang (10).

Hasil penelitian ini sesuai dengan penelitian 75 Mulyana, yang menyatakan bahwa tingkat pengetahuan juga berdampak besar dalam kejadian pneumonia. Pengetahuan ibu tentang kuman atau praktik pelayanan yang bersih dan sehat, atau mengetahui lebih jauh tentang penyakit pneumonia balita, upaya dalam penekanan angka kesakitan dan kematian akan lebih berhasil (11).

Pengetahuan dapat diartikan sebagai kumpulan informasi yang dipahami, diperoleh dari proses belajar selama hidup dan dapat dipergunakan sewaktu-waktu sebagai alat penyesuaian diri, baik terhadap 
diri sendiri maupun lingkungan. Pengetahuan tentang suatu objek dapat diperoleh dari pengalaman guru, orang tua, teman, buku, dan media massa. Dapat disimpulkan dari teori tersebut bahwa pengetahuan responden dapat menjadi guru yang baik bagi dirinya. Dengan pengetahuan yang dimiliki akan mempengaruhi kepatuhan responden dalam melakukan kunjungan ulang. Penderita yang mempunyai pengetahuan tinggi cenderung lebih patuh berobat daripada penderita yang berpengetahuan rendah (12).

\section{Kesimpulan}

Menurut hasil penelitian tidak semua ibu balita membawa kunjungan ulang balitanya, dari hasil penelitian didapatkan hanya $30 \%$ ibu balita yang melakukan kunjungan ulang artinya lebih banyak ibu balita yang tidak melakukan kunjungan ulang sebesar $70 \%$ hal ini karena ada beberapa alasan ibu balita tidak membawa balita penderita pneumonia untuk kunjungan ulang diantaranya anaknya sudah sembuh dan tidak batuk lagi, ada juga ibu balita beralasan sedang sibuk.

\section{Daftar Pustaka}

1. Nurhayati. Evaluasi Pelayanan Manajemen Terpadu Balita Sakit Terhadap Kesembuhan Pneumonia Pada Anak Balita. Berita Kedokteran Masyarakat. Jurnal Online Universitas Gadjah Mada Volume 26, No. 4, Desember 2010, hlm. 211-217. [Cited 14 March 2016]. Available from: https://jurnal.ugm.ac.id

2. Purnamasari, dkk . Pengaruh Pendidikan Kesehatan Pada Orangtua Terhadap Pengetahuan dan Kepatuhan Kunjungan Ulang Balita dengan Pneumonia di Puskesmas Kecamatan Pasar Minggu. Universitas Indonesia, Depok. Tesis; 2010

3. World Health Organization. Integrated Management Of Childhood IIIness : WHO Press; 2010

4. Kemenkes RI. Pedoman Tata Laksana Pneumonia Balita. Jakarta: Kementrian Kesehatan Republik Indonesia; 2015

5. Dinas Kesehatan Kota Banjarbaru. Profil kesehatan Kota Banjarbaru; 2014
6. Depkes RI . Manajemen Terpadu Balita Sakit Modul 3: Menentukan Tindakan dan Pengobatan. Jakarta: Bakti Husada; 2008

7. Ditjen P2PL. Buku Saku Pneumonia Balita Pedoman Kader, Kementrian Kesehatan RI, Jakarta; 2007

8. Vitasari. Hubungan Kepatuhan Kunjungan Ulang dengan Membaiknya Pneumonia Pada Balita Di Puskesmas Piyungan Bantul Yogyakarta. STKES Aisyiyah Yogyakarta. Skripsi; 2007. [Cited 14 March 2016]. Availablle from: http://opac.say.ac.id//Naskah Publikasi

9. Khasanah. Hubungan Kepatuhan Kunjungan Ulang Dengan Kesembuhan Pneumonia Pada Balita Di Puskesmas Piyungan Bantul. STKES Aisyiyah Yogyakarta. Skripsi; 2015. [Cited 14 March 2016]. Availablle from: http://opac.say.ac.id//Naskah Publikasi

10. Pradana. Faktor-Faktor Yang Mempengaruhi Kepatuhan Kunjungan Ulang Ibu Balita Pneumonia Usia 2 Bulan - 5 Tahun Di Wilayah Kerja Puskesmas Gubug I Kabupaten Grobogan". Universitas Negeri Semarang. Skripsi; 2015

11. Mulyana, Agus. Faktor-Faktor Ibu Balita Yang Berhubungan Dengan Kepatuhan Follow Up Penderita Pnemonia Balita Di Puskesmas Cisaga, Ciamis, Jawa Barat, Jurnal Promosi Kesehatan Indonesia, Volume I, No. 2, Agustus 2012.

12. Notoatmodjo, Soekidjo. Metodologi Penelitian Kesehatan, Rineka Cipta: Jakarta; 2010 